\title{
Imaging and Imagining Palestine: An Introduction
}

\author{
Sary Zananiri
}

The British Mandate period in Palestine was a tumultuous time, one that began with the cessation of more than four centuries of Ottoman rule and culminated in the Nakba with the creation of the State of Israel. In this respect, we might view it as a period of significant transition, transformation and, ultimately, displacement and dislocation. From a cultural and social perspective, the Mandate period saw the continuation of the modernisation project begun under the Ottomans. This process is entangled and evident in photographic perspectives, which during this time was also marked by significant shifts and developments in technology that enabled new modes of photography, in turn impacting the imaging and imagining of Palestine.

The first photograph of Palestine was taken in Jerusalem in 1839, the same year in which the process was invented, making it one of the first places in the world to be imaged using the new process. ${ }^{1}$ In the years to follow, photographs of Palestine formed the basis of photobooks and postcards. By the early twentieth century, non-professional photographers began to take similar photographs, as well.

This volume attempts to create a first overview of photography during the British Mandate, bringing together scholars and experts from disciplines ranging from history to cultural studies to architectural theorists, archivists and creative practitioners. It intentionally focuses on the interactions of photographic production and its effects within indigenous Palestinian communities rather than Jewish and Zionist photography of the Yishuv, which although inflected across this volume, is well documented and researched. ${ }^{2}$

In light of this, defining what constitutes Palestinian photography is a controversial topic. Here Issam Nassar offers a useful framework for defining local photography', that is predicated upon questions of photographic production and consumption.

1 Issam Nassar, "Early local photography in Jerusalem," History of Photography 27, no. 4 (2003): 322 .

2 See for instance, Vivienne Silver-Brody, Documentors of the Dream: Pioneer Jewish Photographers in the Land of Israel 1890-1933 (Lincoln, Nebr.: University of Nebraska Press, 1999). 
[L]ocal photography would be any photography that represented social life in Palestine as opposed to the depictions of biblical landscapes, on the one hand, and Zionist photography, which tended to focus almost exclusively on the Jewish settlement project in Palestine, on the other. ${ }^{3}$

Underscoring Nassar's argument here is an understanding that analysis of photography should be intersected with questions of indigeneity, processes of identity formation that shifted radically from the late Ottoman period to the British Mandate, and the effects of migration and mobility both within the Ottoman Empire (during and after its demise), and from elsewhere.

\section{Towards an Understanding of Indigenous Photography in Palestine}

The term 'Indigenous Lens' was discussed and problematised at length by Ritter and Schweiwiller in The Indigenous Lens? Early Photography in the Near and Middle East. Notwithstanding their broader geographical focus, and their focus on photographic histories of the nineteenth century, their definition of an indigenous lens 'serves as a metaphor for local and vernacular photographic practices, visual traditions, actors, uses, and contexts of photography, or in other words, for an alternative view of photo history in the region'. Such designations, of course, overlap and intersect with Nassar's ideas of local photography, but a category of indigenous photography might also give us an understanding of the specificities of local modes of production, consumption and circulation of photography.

Earlier in the Ottoman period, there is the notable example of Menden John Diness. A Jewish immigrant who arrived in 1849, Diness who hailed from Odessa, presents a particularly curious case. He converted to Protestantism amongst much scandal in Jerusalem's international milieu before later emigrating to the US. ${ }^{5}$ His story speaks to transnational and transcommunal political affinities present in Ottoman Palestine as well as the boundaries of communal

3 Issam Nassar, "Familial Snapshots Representing Palestine in the Work of the First Local Photographers," History and Memory 18, no. 2 (2006): 144.

4 Markus Ritter and Staci G. Schweiwiller, eds., The Indigenous Lens? Early Photography in the Near and Middle East, 8. Studies in Theory and History of Photography (Berlin/Boston: De Gruyter, 2017): 12.

5 Dror Wahrman, "Developing a Photographic Milieu: Mendel John Diness and The Beginning of Photography in Jerusalem," in Capturing the Holy Land: M.J. Diness and the Beginnings of Photography in Jerusalem, edited by Dror Wahrman, Carney E. S. Gavin, Nitza Rosovsky (Cambridge MA: Harvard University Press, 1993), 8-35. 
porosity - and indeed the results of their transgression - that would later shape the politicised context of the British Mandate.

In the years before and after Palestine was shifting from Ottoman rule to British Mandate, a number of Jewish, and generally Zionist, art photographers such as Yaacov Ben-Dov, Zvi Oron-Orushkes and Ya'acov Ben Kaltor, to name but a few, migrated to Palestine and came to prominence as photographers under British rule. ${ }^{6}$ Alongside these are slightly later examples of photojournalists that visited or migrated to Palestine against the backdrop of European antisemitism in the 193os like Tim Gidal, Felix H. Man, Kurt Hübschmann, Otto Umbehr, Robert Capa, show the interesting parallels of Zionist transnational mobility of the medium ${ }^{7}$ to the contributions in this volume in which Christianity is predominantly implicated.

Tsadok Bassan is a salient example of Jewish photography in Palestine with which to consider assertions of local and indigenous photography. As a member of the Old Yishuv, born in Jerusalem to a third-generation family in Palestine ${ }^{8}$ he seems exceptional in the categorisation of localness in comparison to other Jewish photographers of the period, though, at the same time, is clearly not indigenous. More research is needed to understand the significance of his practice and his exploration of Old Yishuv communal life, although the assertion he was 'the first Jerusalem photographer' ${ }^{9}$ does actively negate other practices, such as those of early Armenian contributions or Arab figures like Khalil Ra'ad who predate or were contemporaneous to him. Bassan tests the ways in which we might delineate the ascription of indigeneity, but also underscores the complexities, importance and limitations of considering the indigenous lens, particularly given the fraught, contemporary context in which nationalist ideologies colour our understanding of photography in retrospect. For a well-known early Zionist example, we could look to the Russian immigrant Yeshayahu Rafflovich, who was active as a photographer from the

6 A useful and extensive of biographical list of local photographers is compiled by Shimon Lev and Hamutal Wachtel in the catalogue accompanying the exhibition The Camera Man: Women and Men PhotographJerusalem 19oo-1950 (Jerusalem: Tower of David Museum, 2016), 140-126.

7 Rebekka Grossmann, "Image Transfer and Visual Friction: Staging Palestine in the National Socialist Spectacle," The Leo Baeck Institute Yearbook 64, no. 1 (2019): 22-23.

8 Sue Serkes, "For a photogenic Jerusalem, a look at how locals first captured their city," Times of Israel 26th May, 2016. https://www.timesofisrael.com/for-photogenic-jerusalem-a-look -at-how-locals-first-captured-their-city/\#gs.g99sd4.

9 See for instance the exhibition curated by Guy Raz, Tsadok Bassan - Orphan Girls at Jerusalem Artists House, 24th September-13th November, 2005. https://www.art.org.il/?exhibitions =tsadok-bassan-orphan-girls\&lang=en. 
189 os $^{10}$ and more closely typifies patterns of Jewish photographic production in Palestine.

There is currently no evidence of indigenous Jewish-Arab photographic practices, paralleling those of Christian and Muslim Arabs or the ancient and longstanding Armenian community of Palestine prior to its significant expansion resulting from the genocide and World War I. ${ }^{11}$ It is clear, however, that indigenous Jewish communities were, along with many others, photographic subjects for both local and visiting photographers alike, often within the Biblical rubrics outlined below.

The establishment of Jewish-run commercial studios during the Mandate period, such as Palphot, an enterprise that is still active in the 'Holy Land' souvenir market today, ${ }^{12}$ also underscores Jewish participation in the lucrative market for biblical souvenirs. However, Palphot's co-founder Tova Dorfzaun's problematic assertion that 'when we came here, I had to admit I had doubts about succeeding - because there was so little here to photograph,13 displays just one aspect of the conceptual complexities involved in widening the scope of this volume further.

Early photography in Palestine was indeed marked significantly by mobility, from European photographers, both Jewish and Christian, who travelled to the region, as well as internal mobility within the Ottoman Empire. Such internal Ottoman mobility, by the time of the British Mandate and the creation of the new nation-states that exist today, viewed from a current perspective gives an appearance of internationalism to contemporary understandings of national origin. Khalil Ra'ad, born in present day Lebanon, or the works of Armenians like Issay Garabedian or Garabed Krikorian, both born in present day Turkey, are poignant examples. However, Ottoman mobility needs to be viewed within the broader context of Ottoman communalism, the spread of communities and the networks, both local and regional, that enabled them. Notwithstanding the complex context of the shift from Ottoman subjecthood to the new nationalist identifications that were cemented by the borders

10 Yeshayahu Nir, The Bible and the Image: The History of Photography in the Holy Land 18391899 (Philadelphia: Philadelphia University Press, 1986), 248.

11 Raymond Kevorkian, "From a monastery to a neighbourhood: Orphans and Armenian refugees in the Armenian quarter of Jerusalem (1916-1926), reflexions towards an Armenian museum in Jerusalem", in Special issue 'Eastern Christianity in Syria and Palestine and European cultural diplomacy (186o-1948). A connected history', ed. by Karène Sanchez Summerer and Konstantinos Papastathis, Contemporary Levant, 6:1 (2021).

12 Tim Semmerling, Israeli and Palestinian postcards: Presentations of national self (Austin, TX: University of Texas Press, 2004), 13.

13 Ibid 14. 
imposed by the Franco-British authored Sykes-Picot agreement during the World War I, a significant indigenous photographic milieu came to prominence by the time of the British Mandate. This includes the brothers Najīb and Jamāl Albīnā, Ḥannā Ṣāfiyya and the Ḥanāniyya brothers (whose studio would later be bought by Kahvedjian) in Jerusalem, Dāwūd Sabūnjī and 'Isā Sawabīnī (whose Jewish apprentice, Rachmann, would go on to practice in Tel Aviv) ${ }^{14}$ in Jaffa, Zakariyyā Abū Fahīla in Bethlehem and, of course, Karīma 'Abūd who is recognised as the first female professional photographer in the region ${ }^{15}$ to name but a handful. This underscores the significant research yet to be undertaken on photography in Palestine.

\section{$2 \quad$ Modern Images and Biblical Imaginings}

In the last two decades research on photography in and of Palestine specifically, and the Arab World in general, has grown considerably. ${ }^{16}$ Significantly

\footnotetext{
14 Nassar, Familial Snapshots, 146.

15 Issam Nassar, 'Early Local Photography in Palestine: The Legacy of Karimeh Abbud', Jerusalem Quarterly 46 (2011).

16 For instance, Issam Nassar, Patricia Almarcegui, and Clark Worswick, Gardens of sand:
} Commercial photography in the Middle East, 1859-1905 (Madrid: Turner; 2010); Issam Nassar, Photographing Jerusalem: the Image of the City in Nineteenth Century Photography (Boulder: East European Monographs, 1997); Mitri Raheb, Ahmad Mrowat, and Issam Nassar, Karīmah 'Abbūd: rāidat al-tașwìr al-niswì fì Filasțīn, 1893-1940 (Bethlehem: Diyar Press, 2011); Noorderlicht Foundation and Wim Melis, eds, Nazar: Photographs from the Arab world (New York: Aperture, 2004); Hanna Safieh, A Man and his Camera: Hanna Safieh: Photographs of Palestine, 1927-1967 (Jerusalem: 1999); Issam Nassar, European Portrayals of Jerusalem religious fascinations and colonialist imaginations (Lewiston: Edwin Mellen Press, 20o6); Stephen Sheehi, The Arab Imago: A Social History of Portrait Photography, 1860-1910 (Princeton: Princeton University Press, 2016); Markus Ritter, Staci Gem Scheiwiller, eds., The Indigenous Lens?: Early Photography in the Near and Middle East (Berlin: de Gruyter, 2018); Stephen Sheehi, "The Nahda after-image: or all photography expresses social relations," Third Text: Critical Perspectives on Contemporary Art and Criticism 26, no. 117 (2012): 401-414; Gil Pasternak, The Handbook of Photography Studies (London: Bloomsbury Visual Arts, 2020); Elias Sanbar and Salim Tamari, Jérusalem et la Palestine: le fonds photographique de l'École Biblique de Jérusalem (Paris: Hazan, 2013); Rona Sela, Halil Ra'ad, tatslumim 1891-1948 (Tel Aviv: Muze'on Naḥum Guțman, 2010); Ariella Azoulay, From Palestine to Israel: A Photographic Record of Destruction and State Formation, 1947-1950 (London: Pluto, 2011); Elias Sanbar, The Palestinians: Photographs of a Land and Its People from 1839 to the Present Day (New Haven: Yale University Press, 2015); Ali Behdad and Luke Gartlan, eds., Photography's Orientalism New Essays on Colonial Representation (Los Angeles: Getty Research Institute, 2013); Ali Behdad, "Orientalism and the Politics of Photographic Representation", The Trans-Asia Photography Review 10, no. 2 (2020); Ali Behdad, "Mediated Visions: Early Photography of the Middle East and 
however, there is much yet to be said and to be researched as this volume attests, making clear the archival gaps in the field. As photography outside Europe and North America is relegated to regionalised and, implicitly, inferior quality ${ }_{1}^{17}$ one of the most pressing issues in the research of photography in Palestine is, indeed, the question of how the photographic process - one of the technological fruits of modernity - bestows or denies that modernity.

The transformations of the late Ottoman period were many. Modernity was more than just technological or bureaucratic innovation, though these were formative at a macro level. It was also a lived experience that 'colonized local politics, cultural practices, and everyday life by bringing into the discussion a consequence of modernity: modernity draws and redraws boundaries of class, and, critically, the ideas, institutions, and politics associated with modernity have given rise to a uniquely modern middle class'.18

The ways in which modernity and religious narrative collide in the case of the photography of Palestine gives us a particular avenue for understanding different aspects of social history, especially given its prevalence by the time of the British Mandate. Photographs produced in Palestine by indigenous Palestinians and non-Palestinians alike had a significant audience in the West as the many publications from the German Georg Landauer's Palästine: 300 Bilder (1925) in the early the British Mandate period to the Australian war photographer Frank Hurley's The Holy City (1949) just after its disastrous end. ${ }^{19}$

'Holy Land' photography the nineteenth century would develop into a lucrative market, with many Europeans, and later North Americans, Australians and New Zealanders, travelling the region to produce photographs, postcards, travel books and atlases. The reading of the Palestinian landscape through Biblical narrative was commonplace, eschewing the modern in favour of the putatively ancient. Such photographs sit within the rubric of what Nassar describes as

Orientalist Network", History of Photography (2017): 362-375; Ali Behdad, "Orientalism and the history of photography in the Middle East": 82-93 in Inspired by the East, eds. William Greenwood and Lucien De Guise (London, British Museum Press, 2020); Lorenzo Kamel, Imperial Perceptions of Palestine: British Influence and Power in Late Ottoman Times (London: I.B. Tauris, 2016); Amanda Burritt, Visualising Britain's Holy Land in the Nineteenth Century (Cham: Palgrave MacMillan, 2020) have all written about photography and visual culture in Palestine specifically or the region at large.

17 Issam Nassar, "Bearers of Memory: Photo Albums as Sources of Historical Study in Palestine", chapter 5 in this volume.

18 Keith Watenpaugh, Being Modern in the Middle East Revolution, Nationalism, Colonialism, and the Arab Middle Class (Princeton: Princeton University Press, 2006), 8.

19 See for instance Nur Masalha, The Palestine Nakba: Decolonising History, Narrating the Subaltern and Reclaiming Memory (London: Zed Books, 2012) and Ilan Pappe, The Ethnic Cleansing of Palestine (Oxford: Oneworld, 2015). 
biblification, that is, the reading of Palestine through Biblical narrative, effectively projecting the land and its people backwards into an ancient past, while also excising the modern from the photographic frame. ${ }^{20}$

Perhaps unsurprisingly, technological developments also had significant impacts on photography, its production, distribution and circulation. The daguerreotype, developed by Louis-Jacques-Mandé Daguerre in 1839 would give way to Frederick Scott Archer's wet-plate collodion method, which became the standard by late 185 os. Professional studio and landscape photography reached a peak in the 186 os and 1870 os. $^{21}$ The introduction of Box Brownie camera in 1900 sparked a significant technological shift, enabling portable equipment and quick exposures times ${ }^{22}$ and the global economic boom in period after World War I, further democratised the medium, ${ }^{23}$ coinciding with the beginning of the British Mandate in Palestine.

From the context of an earlier photographic market addressing pilgrims and 'arm-chair' tourists at home in the West, ${ }^{24}$ local photographic studios would emerge in Palestine from the late nineteenth century onwards. ${ }^{25}$ The Armenian community was instrumental in the growth of indigenous photographic studios, with the medium introduced locally by the Armenian Patriarch Issay

20 Issam Nasser, "Biblification in the Service of Colonialism:Jerusalem in Nineteenth-century Photography," Third Text 20, no. 374 (2006): 317-326.

21 Zeynep Çelik and Edhem Eldem, eds., Camera Ottomana: Photography and Modernity in the Ottoman Empire, 1840-1914 (Istanbul: Koç University Press, 2015).

22 Brian Coe and Paul Gates, The Snapshot Photograph: The rise of Popular Photography 1888 1939 (London: Ash \& Grant, 1977): 22.

23 Ibid 36.

24 Randy Innes, "Jerusalem Revisited: On Auguste Salzmann's Photo-Topography," Religion and the Arts 15, no. 3 (2011): 306-337; Emmie Donadio, "Seeing is believing: Auguste Salzmann and the photographic representation of Jerusalem," in Jerusalem idea and reality, eds. Tamar Mayer and Suleiman Mourad (Milton Park, Abingdon, Oxon; New York: Routledge, 2008), 140-154; Abigail Solomon-Godeau, "A Photographer in Jerusalem, 1855: Auguste Salzmann and His Times," October 18 (1981): 91-107; Douglas M. Haller, In Arab Lands: The Bonfils collection of the University of Pennsylvania Museum (Cairo: The American University in Cairo Press, 200o), 11-27; Keri Berg, "The imperialist lens: Du Camp, Salzmann and Early French photography," Early Popular Visual Culture 6, 1 (2007): 1-17; Francis Frith, Julia van Haaften, and J.E. Manchip White, Egypt and the Holy Land in historic photographs (New York/London: Dover Publications; Constable, 1980), 77; Douglas Nickel, Francis Frith in Egypt and Palestine: A Victorian Photographer Abroad (Princeton: Princeton University Press, 2004).

25 This includes the studio of Garabed Krikorian, Khalīl Ra'ad, 'Isā Sawabīnī, Karīma 'Abūd and Dāwūd Sabūnjī to name a handful. 
Garabedian to train young Armenians ${ }^{26}$ through the Armenian Patriarchate ${ }^{27}$ quickly giving rise to both Armenian and Arab commercial photographic studios in Palestine. ${ }^{28}$

This underscores several questions fundamental to this volume. Firstly, it highlights the role of the market for photography. That is to say consumers had a strong role in dictating photographic production, whether it was biblified material for the Western market or the commissioning of photography either for personal portraits, ${ }^{29}$ use in scholarship, ${ }^{30}$ or indeed even by the state. ${ }^{31}$ Added to these categories, with the increasing accessibility of the medium, was the growth of amateur photography amongst the middle and upper classes globally, but also, and pertinent to the context of Palestine, amongst soldiers. ${ }^{32}$

Secondly, and related to questions of cultural consumption and production, are the class connotations of photography. While photographic images were becoming increasingly commonplace and accessible, particularly with the invention of the cheap and portable cameras for non-professional use, the medium still required a certain financial investment, skewing access to photographic production by class.

Third, is the role of Christianity. While photography was far from being the sole purview of Christian communities ${ }^{33}$ - either Palestinian or globally the influence of Christianity in photography of Palestine was great. On the one hand, biblified photography was lucrative and greatly in demand in

26 Badr El-Hage, "Khalil Raad - Jerusalem Photographer", Jerusalem Quarterly 11-12 (2001): 34 .

27 George Hintlian is quoted on the subject in Yeshayahu Nir, The Bible and the Image: The History of Photography in The Holy Land, 1839-1899 (Philadelphia: University of Pennsylvania Press, 2017), 121.

28 Salim Tamari, The Great War and the Remaking of Palestine (Berkeley: University of California Press, 2017), chapter 8; Nir, The Bible and the Image: The History of Photography in The Holy Land, 1839-1899, 235.

29 See for instance Issam Nassar, "Early Local Photography in Palestine: The Legacy of Karimeh Abbud", Jerusalem Quarterly 46 (2011): 23-31.

30 For instance, collections related to archaeology such as photographic archives at the Dominican École biblique et archéologique française de Jérusalem or the London-based Palestine Exploration Fund.

31 See for instance Salim Tamari, "The War Photography of Khalil Raad: Ottoman Modernity and the Biblical Gaze," Jerusalem Quarterly $5^{2}$ (2013): 25-37.

32 Coe and Gates, The Snapshot Photograph, 30-35.

33 All we need to do is to look to the example of Muhammad Sadiq Bey's photography of Mecca and Medina in 1861, to see the swift adoption of photography outside of the Christian dominated photographic milieu in Palestine. Stephen Sheehi, The Arab Imago: A Social History of Portrait Photography 186-1910 (New Jersey: Princeton University Press: 2016): 1. 


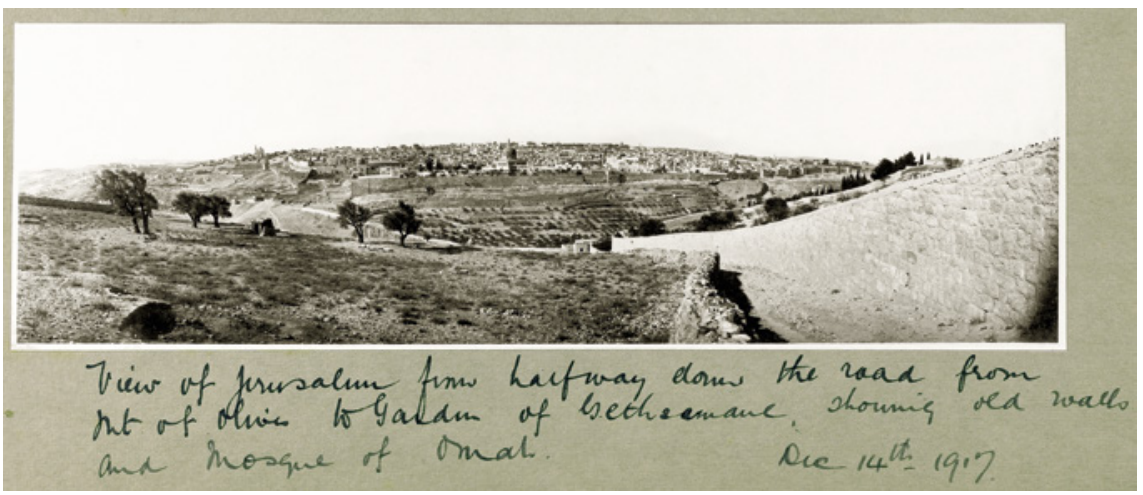

FIGURE 1.1 Jerusalem from the Mount of Olives, 14th December 1917. Captain Arthur Rhodes, The New Zealand Canterbury Rifles

IMAGE COURTESY OF THE PALESTINE EXPLORATION FUND

the western market. On the other, the role of indigenous Christians - both Arab and Armenian - was significant, particularly around the establishment of photographic studios and the commercial practice of photography in Palestine. This reflects the historical diversity and cosmopolitan nature of urban dwellers, a result of the Ottoman policy of higher taxation on minorities, making urban livelihoods increasingly more tenable through the period of Ottoman rule. ${ }^{34}$ This had significant impacts on Palestinian social structure by the British Mandate period. ${ }^{35}$

This process of biblification created a contradiction. Photography was a modern medium that enabled the production and reproduction of images. It has continued, since 1839 , to be the object of constant technological development. However, market dictates of the plural subject matter of the medium - which in the case of Palestine cut across popular, scholarly and state sponsored imaging - delineated and delimited the bestowal of modernity,

34 The impacts of Ottoman taxation regimes in the 17th Century and their aftereffects are dealt with at length in Felicita Tramontana, "The Poll Tax and the Decline of the Christian Presence in the Palestinian Countryside in the 17th Century," Journal of the Economic and Social History of the Orient 56, nos. 4-5 (2013): 631-652. During the British Mandate period, the specific focus of minorities by agents of Western cultural diplomacy further cemented opportunities for Christian Palestinians and the class status they had develop. See, for example, Karène Sanchez Summerer and Sary Zananiri, eds., European Cultural Diplomacy and Arab Christians in British Mandate Palestine, 1918-1948. Between Contention and Connection (London: Palgrave McMillan, 2020).

35 See for instance Sherene Seikaly, Men of Capital: Scarcity and Economy in Mandate Palestine (Palo Alto, CA: Stanford University Press, 2015) or Watenpaugh, Being Modern in the Middle East. 
projecting the image back into the imagined ancient past. By the time of the British Mandate, imaging conventions established during the nineteenth century still held significant sway, despite both the significantly increased accessibility to the medium and its increasingly plural modes of operation. The range of photographs from the British Mandate period show this plurality morphing in different ways: scholarly uses in fields like archaeology or anthropology; commercial portraits, production of souvenirs and travelogues; the documentation of current affairs and social events; humanitarian imaging that marked the plight of orphans and refugees during the turbulent years of the First World War and its aftermath; or information-gathering in the course of urban renewal and, indeed, even espionage. That is to say, many of these photographs actively produced or ruminated upon historical, or quasi-historical, narratives, projecting multiple points of view in which religious narrative is often embedded, sometimes in the subtlest of ways.

\section{Biblification and Orientalism: Towards an Understanding of Legibility in Photography}

Embedded within the tumultuous context of the multifarious medium of photography is an interplay between biblification, Orientalism and modernity. While biblification made legible the landscapes and people of the 'Holy Land' through a process of reading via Biblical interpretation, ${ }^{36}$ Orientalism operated through an inverse procedure. As Edward Said notes in the opening to his seminal work of the same name 'Orientalism is a style of thought based upon an ontological and epistemological distinction made between "the Orient" and (most of the time) "the Occident". ${ }^{37}$

In this regard, we can see the interactions of biblification and Orientalism in photography - and elsewhere - as affecting a process of delimiting and accessioning both the landscapes and people of Palestine into the western Biblical imaginary, whether through scholarly or more popular modes of the medium. While biblification made familiar the foreign other, Orientalism actively marked the delimitation of otherness. The net result of these twin processes is the demarcation of a mode of 'civility'. This civility implicitly attempts to

36 For a longer discussion on Biblical readings of Palestine in imagery, see Sary Zananiri, "From Still to Moving Image: the Shifting Representation of Jerusalem and Palestinians in the Western Biblical Imaginary", Jerusalem Quarterly 67 (2016): 64-81. 
assume the neutral positioning of a western Biblical imaginary that is rooted in the lived experience of modern western bourgeoisie. That is to say, a recouping of the ancient spiritual roots of Western Christianity set against the wild and untameable otherness of an implicitly Islamic 'Orient'.

Implicit, and perhaps complicit, in this twin process is the role of modernity. The assumptions of progress, objectivity and the scientific neutrality of modern methodologies (and the subsequent Occidental attitudes to civil questions of education, health, welfare and the built environment that it entails), produced a thoroughly partial and subjective point of perspective from which biblification and Orientalism, as imaging systems, are constructed. This parallels the broader social and cultural contexts that are explored in a number of the contributions included in this volume.

Within the often transnational histories of imaging Palestine, we find a complex confluence of actors involved in photographic production, photographic subjects, circulation networks and audiences. These also need to be read within the context of Palestinian class structures, in which middle-class urban Palestinians, participated. It is worth noting the over-representation of Christians in this middle-class, ${ }^{38}$ particularly in cities like Jerusalem, with its significant photographic market.

This matrix of class dynamics and transnationalism produces particularised perspectives. With few exceptions, Western photographers tended to focus on biblified production, often rural communities cast as heirs of an ancient Biblical past, holy sites and Biblical archetypes for circulation in the West. Meanwhile, local photographers variously addressed similar international markets, but also worked on commission for local middle-class populations, institutions and the state(s). This dynamic produced skewed visions of Palestine and its social histories during the Mandate that cut across class divides. ${ }^{39}$ Figures such as rural fallähìn (villagers or peasants) or Bedouins, along with other indigenous curiosities for the Western market like the Samaritans or the Domari (often described as Nawar in Arabic or 'Gypsies' in English), for instance, may have heavily populated ethnographic elements the Biblical lens as photographic subjects, but sustained examples of photographic production from

38 See for instance Salim Tamari, Mountain against Sea. Essays on Palestinian Society and Culture (Berkeley: University of California Press, 2008).

39 Jewish communities in Palestine can be seen as operating across a similar binary between ancient biblical actors and modern subjects, but embedded within Zionist ideology, and its reception particularly in Europe, was the fundamentally modern nature of the Zionist project. Rebekka Grossmann deals with this tension at length in "Negotiating Presences: Palestine and the Weimar German Gaze," Jewish Social Studies 23, no.2 (2018): 137-172. 
within such communities are rare to come by, if they exist at all, and present very significant gaps in current historiography, let alone attempts to decolonise the photography of Palestine.

The absent-present qualities of such communities underscore the relationship of photographer to camera, and camera to subject, hinting at the extent of archival silences in textual material into which photography may give us some insight. Several chapters in this volume address the silent role of such relations in Palestine and further afield, with workers, peasants, Samaritans, Bedouins and Domari who are often well recorded in photography, but only minimally discussed, and generally not by name in corresponding textual records, while middle class actors, regardless of their ethnic, religious or national backgrounds are much better represented.

In one of the discussions during the conference ${ }^{40}$ that led to this publication, Stephen Sheehi described the relationship between biblification and modernity as a mode of Biblical Moderne, a useful tool for thinking through the paradoxical push-pull temporality of photography in Palestine. At one and the same moment a product of modernity, but also constantly recalling, if not actively imposing, the Biblical past.

This certainly raises questions about the configuration of biblification, Orientalism and modernity and the ways in which the putative ancient past is remediated to the understanding and aestheticisation of the more recent past on which this volume is focused. The attempts to reconcile the Biblical and the scientific that the Biblical Moderne entails can be seen as an attempt to reconcile the spiritual and the temporal. It could, indeed, be argued that organisations such as the Pro-Jerusalem Society, under the auspices of Charles Ashbee, went so far as to actualise the Biblical Moderne in stone and mortar ${ }^{41}$ with the urban planning policies that they developed in Jerusalem as a consequence of the British occupation of Palestine.

In curating this volume, a diversity of material was sought to reflect the breadth of different photographic archives. The various chapters engage with archives from the scholarly to those which were commercial in nature and, of course, archives of home photography that developed significantly during the course of the Mandate. In dealing with such a plethora of material, this volume

40 Imaging and Imagining: Photography and Social History in British Mandate Palestine was held at Leiden University, 16-18 October 2019 and convened by the editors as part of Nwo (the Dutch Research Council) vidi project CrossRoads: European Cultural Diplomacy and Arab Christians. A Connected History (1920-1950).

41 The impacts of the Pro-Jerusalem Society are dealt with at length in Rana Barakat, "Urban Planning, Colonialism and the Pro-Jerusalem Society", Jerusalem Quarterly 65 (2016), 22-34. 
considers the ways in which different modes of photography shed light on social histories. Likewise, this volume intentionally addresses these different modes through an interdisciplinary framework, bringing a diversity of expertise necessary to approach the already diverse archival context.

The title Imaging and Imagining Palestine attempts to deal with the oftenfraught contradictions of photography in Palestine. The ambiguous nature of photography, which purports to be a process of 'documentation', shapes, frames and narrates Palestine across a plethora of fields, as the following chapters make clear.

This volume is divided into three sections. The first deals with specific archives containing photography in Palestine, the second with individual photographers and the third with conceptual approaches to photography. This taxonomy neatly divides the chapters by their approaches. But, beyond these broad ways of engaging with the subject, the interdisciplinary nature of the contributions and contributors addresses a number of different themes in terms of subject matter.

Often, the modern social apparatus that is tethered to photography ultimately relies on Biblical tropes developed in the nineteenth century. One particular poignant example is humanitarian photography, as explored by Abigail Jacobson. As Jacobson shows, the sponsorship of orphans in the American Colony's Christian Herald Orphanage was the practice of a modern institution with a transnational remit. But, it was fundamentally linked to American philanthropy centred on Protestant Christian networks, with photographic materials using Orientalist tropes to garner donations to charities. Even though the material she discusses effectively deals with the impacts of modernity, in this case the aftereffects of the First World War with its social and cultural ramifications, Christian narratives are fundamental to the questions of charity with which she deals, effectively purveying new modes of biblification, through auspices of the charitable.

The photographs of Inger Marie Okkenhaug's chapter shows the role of Swedish aesthetics in mediating a position between the Arab communities that sat within the remit of the Swedish School, funders in Sweden and the American Colony. The images hint at the social dynamics where the increasingly Palestinian teaching staff intermingled with an ordered Swedish world. Okkenhaug's chapter gives us a sense of the ways in which cultural affiliation and cultural diplomacy interacted within the visuality of the Swedish School. 
Karène Sanchez Summerer and Norig Neveu's chapter also deals with transnational connections, in the form of the École biblique et archéologique française de Jérusalem (EBAF), a photographic collection that drew from a number of Catholic missionary institutions in Palestine. They deal with the diverse nature of Catholic imaging of Palestine from more scholarly archaeological and anthropological photographs to more personal collections that indicate the changing relationships between the missionaries and their congregants and were used for reporting either to national or religious authorities. The chapter traces the diversity of photographic material produced by EBAF, and other associated Catholic agencies, tracing how photographic production shifted over the course of the Mandate.

Issam Nassar's chapter is the only one which deals overtly with nonprofessional photography. Nassar looks at three family albums as an archival source, analysing the ways in which each are narrated. The albums of Wasif Jawharriya, Julia Luci and George Mushabak each narrate a particular perspective on the British Mandate period, giving us a comparative set of micro-histories. The nature of such albums, designed for private uses and circulations, focuses more on life events than nationalist politics of the day. In conceiving of the importance of such photography, Nassar points to their use in understanding the quotidian middle-class urban life.

Rona Sela considers similar remediations of Palestine from an indigenous lens with the works of Khalil Ra'ad, particularly in relationship to his archaeological photography. Sela argues that Ra'ad's engagement with New Testament narrative and archaeology provides an insight into nationalist reconfigurations of biblification and that, as an Arab Christian, his work engages carefully with the colonialist overtones of archaeology and biblified cultural material through the photographic market itself.

Rachel Lev also deals with a singular photographer, John D. Whiting from the American Colony in Jerusalem. Lev's chapter cross-references the Palestinian born Whiting's photographic albums with his travel diaries. In linking the two sources, Lev traces a plural photographic practice looking at the ways in which Whiting negotiated a position between his upbringing in Jerusalem and his American identity. Delving into Whiting's broad corpus, she considers his role in producing publications about Palestine, brokering collections of cultural materials for travellers, facilitating tours and even intelligence gathering, all of which underscore his position as a mediator between Palestine and world beyond, particularly the USA.

This transnational connection can also be seen elsewhere. The Frank Scholten Collection, in particular, gives us a sense of the complexities of transnational connection. The intention behind the production of Scholten's large 
corpus was fundamentally vested in the Biblical, but he also undermined typical readings by going into great detail around the ethnic, confessional and class dynamics of his subjects. His taxonomic methodology, which borrowed from disciplines as diverse as theology, art history and sexology, cut across confessional divides whilst also reifying communal description, a significant example, indeed, of the collision of religious and scholarly narrative that the Biblical Moderne entails.

Yazan Kopty looks at single collection, the National Geographic Society's accumulation of photographic images of Palestine and how we might re-interpret the collection through a contemporary lens. Kopty's chapter deals with an institutional acquisition of photographs from multiple sources and poses multiple questions that problematise the photographic gaze, proposing to recoup readings and re-articulations of such biblified photographic material. Given the historical entwinement of colonialism and photography in the imaging of Palestine, Kopty proposes an indigenisation of the archive through his project Imagining the Holy, positioning this as an alternative framework within contemporary calls for decolonisation. Such a project is particularly useful in reinstating the social histories of such archives through community sourced accounts, bringing to bear the elision of personal histories through contemporary technologies.

Likewise, Stephen Sheehi's contribution proposes a conceptual method for re-envisioning photography in Palestine. Sheehi's methodology provocatively invites us to radically rethink the truth-value of photographs and their role in (re)constructing social history. He questions attempts to seek the 'truth value' of photography, seeking to clarify a methodology of decolonisation as distinct from a project that seeks to recover lost histories. Sheehi proposes a 'seizure of the means of knowledge production', complicating such a call further with the problem of class, as fundamental to understanding the implications of photography. The chapter underscores the amount of work yet to be done, both in dealing with unpublished archives, but more importantly in reconceptualising the field of photography in Palestine in its entirety.

Focusing on the impacts of aerial photography, Nadi Abusaada considers the weight brought to bear by a pairing of dual forces: the technological development of the medium and the impacts of Biblical and Orientalist images of Palestine in shaping attitudes to the built environment and the urban modernisation project itself. In doing so, Abusaada considers the romanticisation of architectural heritage, but also the ways in which such heritage was radically altered and reshaped in the light of colonial modernity. Like Frank Scholten, his paper exemplifies ideas of the Biblical Moderne in producing the British colonial landscape of the Mandate era. 
Photographs of the Mandate era continue to circulate through many networks, often acquiring new meanings in their remediation. What is clear across all contributions to this volume is that photography is a medium that was designed to be reproduced and circulated, and that this has particular significance in the case of Palestine.

Imaging and Imagining Palestine re-examines the possibilities of recouping aspects of the past through the study of photography. It considers the state and institution building so fundamental to the British Mandate period, as well as their significant undoing by its close, grappling with networks implicitly embedded in such enterprises. It also attempts to contextualise them within a broader transnational narrative that better explains the complex social milieu in Mandate Palestine.

This edited volume thus asks crucial questions. What can photographs tell us of the British Mandate as a site of connection and interconnection? How has the meaning of photographs taken in the period shifted since their initial production? Do they indeed present possibilities for recouping the past? What information does the analysis of photography, both as a record itself and in its the afterlife of circulation, yield for the research of social histories?

If we are to take photography - a significant marker of cultural production as an index of the complex social histories involved in networks of production, consumption and distribution, then perhaps a Cultural Studies approach to cultural diplomacy, like that of David Clark, might represent a useful model for framing the social, cultural and political importance of photography. $\mathrm{He}$ defines four actors in his approach to meaning-making in cultural diplomacy: policy makers, agents (both institutional and individual) who implement cultural diplomacy, cultural practitioners and cultural consumers. ${ }^{42}$ In thinking about the process of meaning-making, those actors who are producing photographs are equally engaged as those who are consuming photographic production. He stipulates that:

Cultural consumption is, firstly, a complex process of meaning-making, in which the boundary between cultural 'producers' and 'consumers' is blurred; and, secondly, that in the realm of culture both production and consumption are intrinsically bound up with the articulation and negotiation of identity in a social context. ${ }^{43}$ tural studies perspective," International Journal of Cultural Policy 22, no. 2 (2016): 154. 
The actors considered in this volume are involved in production ranging from commercial photographers to recorders of humanitarian crises, archaeologists and ethnographers, indigenous and foreign alike, with these categories often overlapping, let alone the plethora of cultural consumers. We might look to Abusaada's chapter to see the direct intersections of policy-making and photography in the shaping urban life. But for most chapters, a convoluted matrix of agents, practitioners and consumers dictate the ways in which the market and implicitly Christianity - shaped the photography of the Mandate period.

The implications of meaning-making for Palestinian social and cultural histories is significant in thinking through the context of photography. It upends straightforward readings of photographic production, but also beckons further analysis of such complex networks. ${ }^{44}$ The cultural consumers involved in the process of meaning-making are as varied as the agents and practitioners involved in its production and, given our chronological distance from the period, are also an unstable and changing demographic. They might include pilgrims, tourists, scholars, governmental agents, donors, private networks of friends and acquaintances and of course those for whom Palestine had religious resonances.

Photographic Instability: Old Photographs and New Meanings

Part of the problem in imaging Palestine is that so much weight is brought to bear on an image. Images, and photography in particular, have become part of both the contestation and substantiation of political narrative. In the highly politicised terrain of Palestine, photographs have come to be regarded as 'modes of proof' about a historical past. The impact of lineages of imaging systems before, during and since the British Mandate has had consistent effects on the ways in which we might think about the medium and the state of perpetual cultural, social and political turbulence since. This political turbulence makes for an increased instability of the photographic document, particularly in retrospect.

A poignant example of this instability of the photographic document is exemplified by the series of photographic exhibitions curated by Ali Kazak, the former Director of the PLO Information Office, in Australia. The first

44 We might look to further complications of these networks as does Behdad in regards to the Orientalist networks of photography in the nineteenth century. See Ali Behdad, "Mediated Visions: Early Photography of the Middle East and Orientalist Network," History of Photography: Special Issue: Photography and Networks, guest eds. Owen Clayton and Jim Cheshire, 41, no. 4 (2017): 362-375. 
exhibition was held in Storey Hall, at the Royal Melbourne Institute for Technology in 1979. While many of the photographs dealt with contemporary political issues - sometimes in brutally graphic ways - a significant section of the exhibition was dedicated to the use of historical imagery, particularly biblified and Orientalist representations of Palestine, both as prints and photographs. Kazak asserts that such material was useful in proving the existence of the Palestinian people in the political context of 1970s and 8os Australia. Arguably, it also points the shifting self-perception of Palestinians, in line with the reimagining of the Palestinian falaheen as a symbol of Marxist resistance so prevalent in the period, which had an overlap with the class-skewed images produced by Orientalist and biblified imaging. In this way, the use of popular Western historical imagery became a means to subvert political discourse, effectively challenging their representational limitations, and perhaps the intention of the original works, in a period before digital technologies enabled easy access to and circulation of images.

The enormous shifts in digital technological developments have enabled photographs to circulate in ways that were unthinkable in the periods when the original photographs were originally produced. Facebook groups such as Mona Halaby's British Mandate Jerusalemites Photo Library use such means to attempt to recoup the past through period-specific photographic materials drawn from institutional and family archives alike, in this case providing a public platform with over 20,000 followers. ${ }^{45}$ Such platforms are knowledge-sharing devices with a public interface, but have their effects on the process of meaning-making, generating new meanings in the ways in which they (re-)instate Palestinian narrative. Notwithstanding the reliance on materials available from the period (and the social biases inherent to such material), through Halaby's carefully researched textual annotations, as well as those sourced from her interlocutors and followers, photographic materials are animated and activated in ways that traditional archives are not, making it a community locus as well as a page of much research interest for those in the field.

On an institutional level, the Palestine Museum initiated a digitisation project aimed at documenting and preserving family albums in $2015 .{ }^{46}$ The ongoing family album project operated under the slogan 'Your memories, your pictures,

45 See British Mandate Jerusalemites Photo Library, https://www.facebook.com/BMJeru salemitesPhotoLib/, accessed 3rd May, 2021.

46 The fruits of this and other digitisation initiatives by the Palestine Museum can be viewed through their online portal https://palarchive.org. 


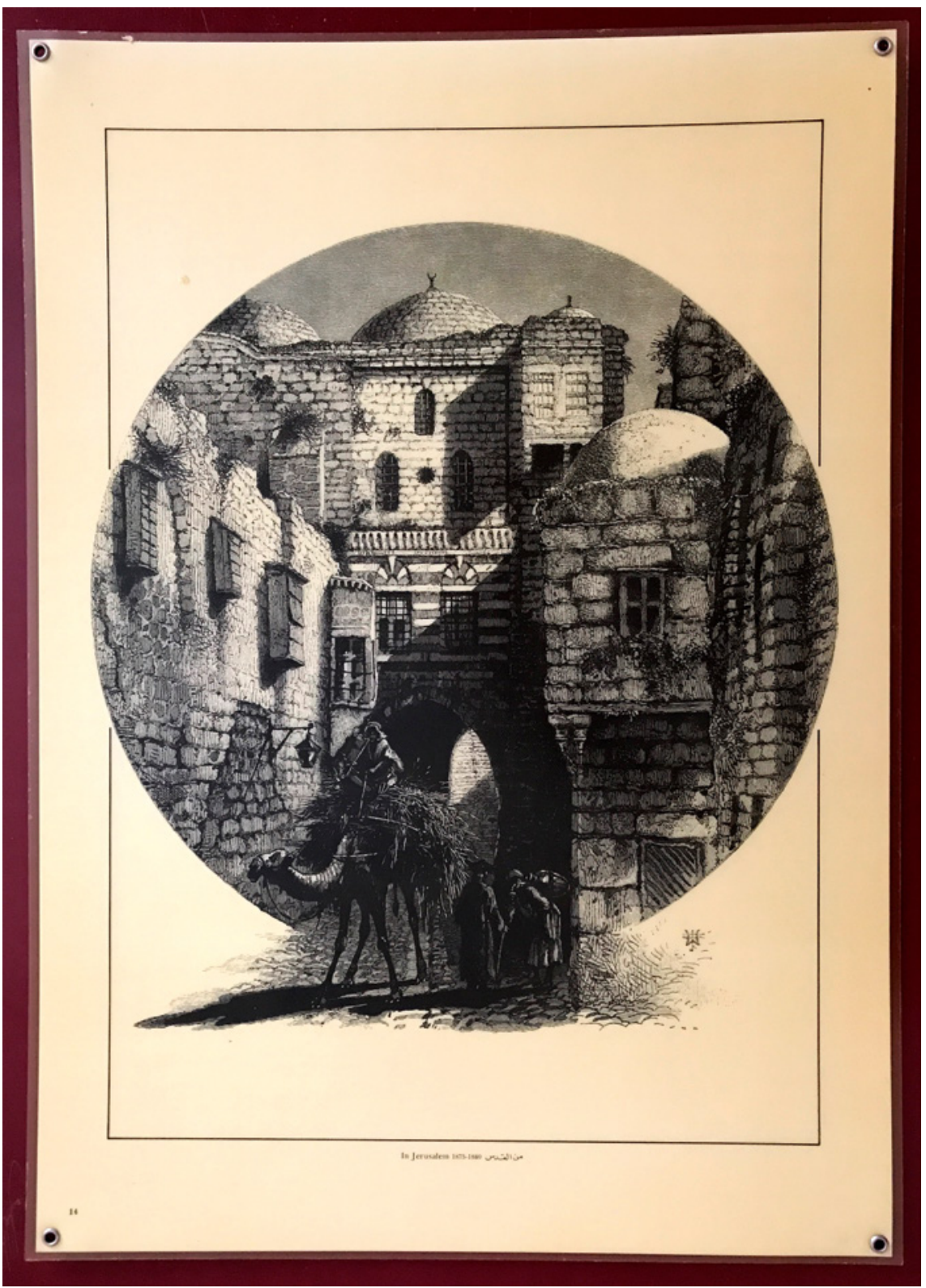

FIGURE 1.2 A reproduction from Ali Kazak's exhibitions on Palestine, 1979. Mostly likely reproduced from Captain Charles Wilson's Picturesque Palestine (1891)

IMAGE COURTESY OF ALI KAZAK 
our heritage. ${ }^{47}$ The instatement of the national through the social underscores the cultural importance associated with the documentation of daily life in what had typically been the preserve of the private sphere. The archive, which spans a considerably larger period than just the British Mandate, shows the development of intimate familial portraiture and, from a social and technological perspective, the ways in which family snapshot photography evolved over time, making it important not just as a project for Palestinian history, but indeed a chronological study of the medium itself.

The Palestine Museum's digitisation presents a very different strategy to Kazak's earlier Australian exhibitions. While both insist on photography and image production practices as important modes of disseminating Palestinian narrative, a shift in focus from Western cultural production to a focus on domestic photographic practices emphasises the significant growth in interest of indigenous voice, in this case through the accumulation of micro histories rooted in the family album.

The need for a comprehensive overview of Palestinian photography during the British Mandate is all the more urgent with the growth of online archives, image repositories and digital humanities methodologies. With the digitisation of photographic collections, images are more available than ever before. The need to research and contextualise such material is all the more important to understand the shortcomings of photography and the photographic archive as well as what they explicate that other primary sources of historical study do not.

It is also clear that the photographic archives to which we refer are also prone to their own biases, by virtue of the market, questions of the socio-economic status of producers, and the rubrics of Christianity, both in the production and marketing of photography in and from Palestine. This underscores the significant amount of work that still needs to be undertaken. Much work has looked at biblification with respect to Western collections and such materials have already been analysed as products of colonial claim, ${ }^{48}$ effectively underscoring cultural entwinement with political policy.

With the implications of biblification, Christian narratives create a multifarious series of interactions that intersect with class. While on the one hand the representation of Palestine and Palestinians in both photography and scholarship led to significant erasures, it is also evident that class formation

\footnotetext{
47 'The Palestine Museum's Family Album Project: The Intimate Side of Life in Palestine' press release from the Palestine Museum 13th May 2015, reproduced by Jadaliyya, accessed 27th October 2020 https://www.jadaliyya.com/Details/32080.

48 Nassar, "Biblification' in the Service of Colonialism", 317-326.
} 


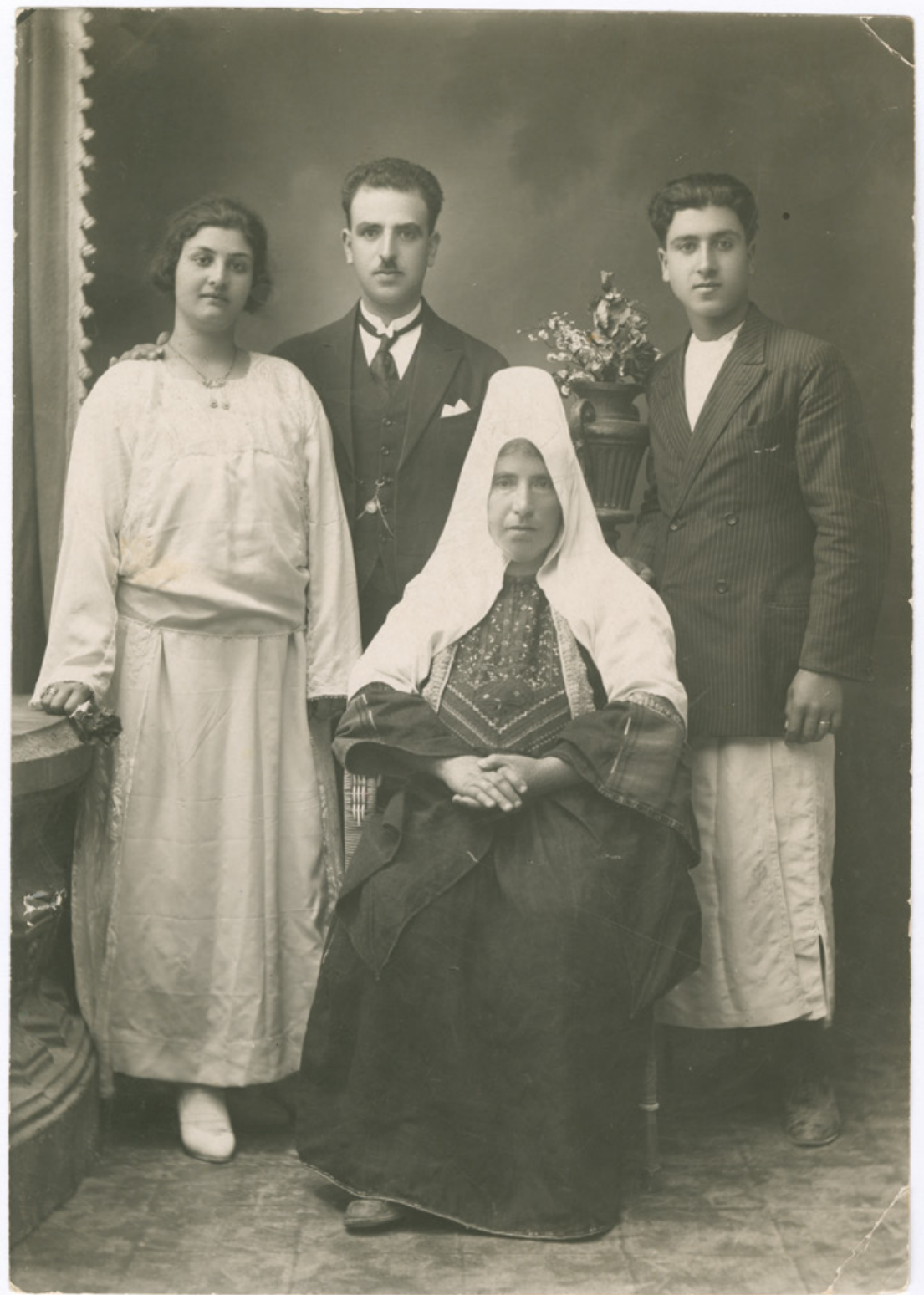

FIGURE 1.3 Hanna Bastoli and family members on her engagement day, 1924. (Hanna Bastoli, George Ayyoub and her mother-in-law, Hilwa Al-Douiri). From Maha as-Saqqa's photo album, 0027.01.0054

IMAgE COURTESY OF THE PALESTINE MUSEUM AND MAHA AS-SAQQA 


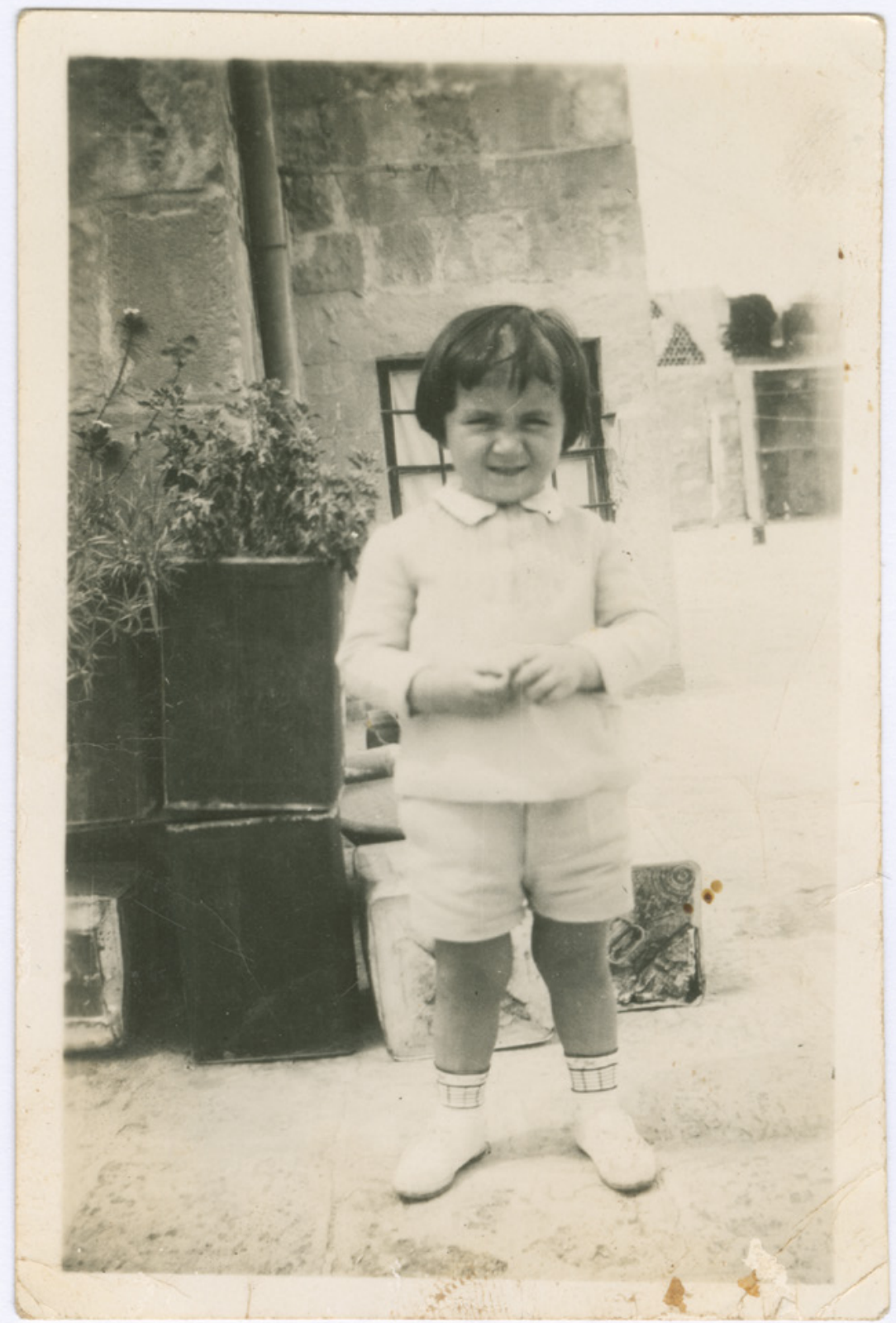

FIGURE 1.4 Bassam Shakaa as a child, 1933. From the Bassām ash-Shak'a's photo album, 0050.01 .0386

IMAGE COURTESY OF THE PALESTINE MUSEUM AND ASH-SHAKAA FAMILY 


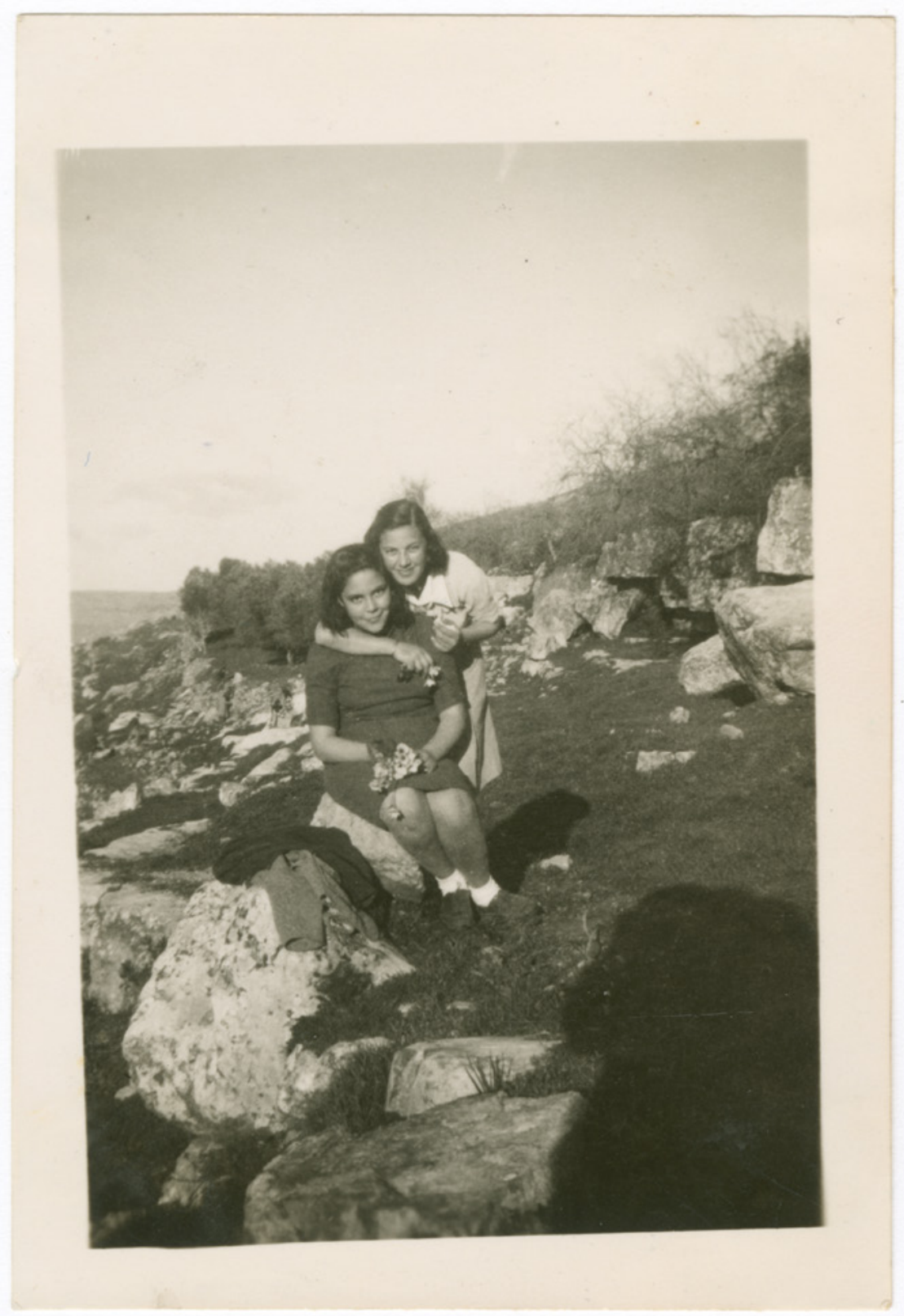

FIGURE 1.5 A family trip with friends, c.1940-45. Ghassan Abdullah Collection, 0156.01.0068 IMAGE COURTESY OF THE PALESTINE MUSEUM AND THE ABDULLAH FAMILY 
and modernity played a significant role in the selective highlighting of certain Palestinian groups over others. Internal Palestinian dynamics of class formation also point toward mercantile Palestinian complicity in the photographic erasure of Palestinian modernity, through the proffering of biblified materials to the Western photographic market. This is an irony given that this was precisely the same class most actively involved in the documentation of Palestinian modernity through carte de visites and other forms of photography in the nineteenth and early twentieth century ${ }^{49}$ or through vernacular photography in the interwar period. As Sheehi reminds us in his chapter, 'the decolonisation of photography is not magical undoing ... an ahistorical process or a reading through nationalist frameworks that sees indigenous photography as 'speaking back' to power ... [the] decolonisation of photography should not seek an 'epistemic reconstruction' ... awaking dormant histories are not the same as hoping to resurrect arcane or dead practices, fetishising them as authentic culture'.

A Palestinian deployment of Biblical narrative in the case of photographers like Khalil Racad, can also be viewed as an intervention into biblification as an imaging system when read within the category of agents in Clark's cultural studies approach to meaning-making in cultural diplomacy. Racad used the international interest in the biblified photography of Palestine as a platform for proffering an indigenous vision that counters the colonial lens. Arguably, the photographs from the Armenian General Benevolent Union in the epilogue, that will be included as part of the collections in the new Armenian Museum in Jerusalem, also implicitly deployed the Biblical in requests for humanitarian donations from the West. In considering Palestinian agency, it does raise important questions about how biblification and its transmission between Palestinians and Europeans functioned. A partial answer can be found in question of class dynamics and the urban-rural divide in Palestinian society.

This volume synthesises both social history and photography, attempting to garner an overview of the British Mandate. But also, this volume shows us the limitations of photography as a study for social history, particularly in relation to questions of class, confession and colonialism, let alone questions of gender and sexuality. Given this, we proffer this volume as a gesture towards mapping the plurality of photography, its circulations and its conceptualisation, both during the Mandate period and in retrospect since.

49 See Stephen Sheehi's chapter, "The Carte de Visite: The Sociability of New Men and Women," in his book The Arab Imago: A Social History of Portrait Photography 1860-1910 (Princeton: Princeton University Press, 2016), 53-74. 


\section{Bibliography}

Azoulay, Ariella. From Palestine to Israel a photographic record of destruction and state formation, 1947-1950. London: Pluto, 2011.

Behdad, Ali and Gartlan, Luke, eds. Photography's Orientalism new essays on colonial representation. Los Angeles: Getty Research Institute, 2013.

Behdad, Ali. "Mediated Visions: Early Photography of the Middle East and Orientalist Network." History of Photography: Special Issue 'Photography and Networks', guest editors Owen Clayton and Jim Cheshire 41, no. 4 (2017): 362-375.

Behdad, Ali. Orientalism and the Politics of Photographic Representation. Ann Arbor, MI: Michigan Publishing, University of Michigan Library.

Behdad, Ali. "Orientalism and the History of Photography in the Middle East". In Inspired by the East, edited by William Greenwood and Lucien De Guise, 82-93. London, British Museum Press, $202 \mathrm{O}$.

Berg, Keri. "The imperialist lens: Du Camp, Salzmann and early French photography." Early Popular Visual Culture 6, 1 (2007):1-17.

British Mandate Jerusalemites Photo Library. https:/www.facebook.com/BMJeru salemitesPhotoLib/.

Burritt, Amanda. Visualising Britain's Holy Land in the Nineteenth Century. Switzerland: Palgrave Macmillan, 202O.

Capturing the Holy Land: M.J. Diness and the Beginnings of Photography in Jerusalem. Cambridge MA: Harvard University Press, 1993.

Clarke, David. "Theorising the role of cultural products in cultural diplomacy from a cultural studies perspective." International Journal of Cultural Policy 22, no. 2 (2016): 147-163.

Çelik, Zeynep and Edhem Eldem, eds. Camera Ottomana: Photography and Modernity in the Ottoman Empire, 1840-1914. Istanbul: Koç University Press, 2015.

Coe, Brian. and Gates, Paul. The snapshot photograph: The rise of popular photography, 1888-1939. London: Ash and Grant, 1977.

Donadio, Emmie. "Seeing is believing: Auguste Salzmann and the photographic representation of Jerusalem." InJerusalem Idea and Reality, edited by Tamar Mayer and Suleiman Mourad, 140-154. Milton Park, Abingdon, Oxon; New York: Routledge, 2008.

El-Hage, Badr. "Khalil Raad - Jerusalem Photographer", Jerusalem Quarterly 11-12 (2001): 34-39.

Frith, Francis, van Haaften, Julia, and Manchip White, J.E. Egypt and the Holy Land in Historic Photographs. New York/London: Dover Publications; Constable, 198o.

Grossmann, Rebekka. "Negotiating Presences: Palestine and the Weimar German Gaze." Jewish Social Studies 23, no. 2 (2018): 137-172. 
Grossmann, Rebekka. "Image Transfer and Visual Friction: Staging Palestine in the National Socialist Spectacle." The Leo Baeck Institute Yearbook 64, no, 1 (2019): 19-45. Haller, Douglas, M. In Arab lands: The Bonfils collection of the University of Pennsylvania Museum. Cairo: The American University in Cairo Press, 2000.

Innes, R. "Jerusalem Revisited: On Auguste Salzmann's Photo-Topography." Religion and the Arts 15, no. 3 (2011): 306-337.

Kamel, Lorenzo. Imperial Perceptions of Palestine: British Influence and Power in Late Ottoman Times. London: I.B. Tauris, 2016.

Kevorkian, Raymond. "From a monastery to a neighbourhood: Orphans and Armenian refugees in the Armenian quarter of Jerusalem (1916-1926), reflexions towards an Armenian museum in Jerusalem." In Special issue 'Eastern Christianity in Syria and Palestine and European cultural diplomacy (186o-1948). A connected history', guest editors Karène Sanchez Summerer and Konstantinos Papastathis, Contemporary Levant, 6: 1 (2021).

Lev, Shimon. and Wachtel, Hamutal. Catalogue accompanying the exhibition The Camera Man: Women and Men Photograph Jerusalem 19oo-1950. Jerusalem: Tower of David Museum, 2016.

Masalha, Nur. The Palestine Nakba: Decolonising History, Narrating the Subaltern and Reclaiming Memory. London: Zed Books, 2012.

Nassar, Isssam. Photographing Jerusalem: the image of the city in nineteenth century photography. Boulder: East European Monographs, 1997.

Nassar, Issam. "Early local photography in Jerusalem." History of Photography 27, 4 (2003): 320-332.

Nassar, Issam. European portrayals of Jerusalem religious fascinations and colonialist imaginations. Lewiston: Edwin Mellen Press, 2006.

Nassar, Issam, "Familial Snapshots Representing Palestine in the Work of the First Local Photographers." History and Memory 18, no. 2 (2006): 139-155.

Nasser, Issam. "Biblification' in the Service of Colonialism: Jerusalem in Nineteenthcentury Photography." Third Text 20, issue 374 (2006): 317-326.

Nassar, Issam, Patricia Almarcegui, and Clark Worswick eds. Gardens of sand: commercial photography in the Middle East 1859-1905. Madrid: Turner, 2010.

Nickel, Douglas. Francis Frith in Egypt and Palestine: A Victorian photographer abroad. Princeton: Princeton University Press, 2004.

Nir, Yeshayahu. The Bible and the Image: The History of Photography in The Holy Land, 1839-1899. Philadelphia: University of Pennsylvania Press, 2017.

Noorderlicht (Foundation) and Melis, Wim. Nazar: photographs from the Arab world. New York: Aperture 2004.

Palestine Museum “The Palestine Museum's Family Album Project: The Intimate Side of Life in Palestine" Press release, 13th May 2015, reproduced by Jadaliyya, https:// www.jadaliyya.com/Details/3208o. 
Pappe, Ilan. The Ethnic Cleansing of Palestine. Oxford: Oneworld, 2015.

Pasternak, Gil. The Handbook of Photography Studies. London: Bloomsbury Visual Arts, 2020.

Raheb, Mitri., Mrowat, Aḥmad., and Nassar, Issam. Karimah 'Abbūd: rāidat al-tașwīr al-niswì fí Filasțīn, 1893-1940. Bethlehem: Diyar Press, 2011.

Ritter, Markus and Schweiwiller, Staci, eds., The Indigenous Lens? Early Photography in the Near and Middle East, 8. Studies in Theory and History of Photography. Berlin/ Boston: De Gruyter, 2017 http://search.ebscohost.com/login.aspx?direct=true\&scope $=$ site $\& \mathrm{db}=$ nlebk $\& \mathrm{db}=$ nlabk $\& \mathrm{AN}=1684601$.

Safieh, Hanna. 1999. A man and his camera: Hanna Safieh: photographs of Palestine, 1927-1967. Jerusalem: Raffi Safieh.

Said, Edward. Orientalism. New York: Vintage Books, 1979.

Sanbar, Elias and Tamari, Salim. Jérusalem et la Palestine: le fonds photographique de l'École Biblique de Jérusalem. Paris: Hazan, 2013.

Sanbar, Elias. The Palestinians: Photographs of a Land and its People from 1839 to the Present day. New Haven: Yale University Press, 2015.

Sanchez Summerer, Karène and Zananiri, Sary, eds. European Cultural Diplomacy and Arab Christians in British Mandate Palestine, 1918-1948. Between Contention and Connection. London: Palgrave McMillan, $202 \mathrm{O}$.

Seikaly, Sherene. Men of Capital: Scarcity and Economy in Mandate Palestine. Palo Alto, CA: Stanford University Press, 2015.

Sela, Rona. Halil Ra'ad, tatslumim 1891-1948. Tel Aviv: Muze'on Nahum Guțman, 2010.

Semmerling, Tim. Israeli and Palestinian postcards: Presentations of national self. Austin, TX: University of Texas Press, 2004.

Serkes, Sue. "For a photogenic Jerusalem, a look at how locals first captured their city," Times of Israel 26th May, 2016. https://www.timesofisrael.com/for-photogenic -jerusalem-a-look-at-how-locals-first-captured-their-city/\#gs.g9gsd4.

Sheehi, Stephen. 2012. "The Nahdia after-image: or all photography expresses social relations". Third Text: Critical Perspectives on Contemporary Art and Criticism. 26 (117): 401-414.

Sheehi, Stephen. The Arab Imago: A Social History of Portrait Photography 1860-1910. Princeton: Princeton University Press, 2016.

Silver-Brody, Vivienne. Documentors of the Dream: Pioneer Jewish Photographers in the Land of Israel 189o-1933. Lincoln, Nebr.: University of Nebraska Press, 1999.

Solomon-Godeau, Abigail. "A Photographer in Jerusalem, 1855: Auguste Salzmann and His Times.” October 18 (1981): 91-107.

Tamari, Salim. Mountain against Sea. Essays on Palestinian Society and Culture. Berkeley: University of California Press, 2008.

Tamari, Salim. "The War Photography of Khalil Raad: Ottoman Modernity and the Biblical Gaze." Jerusalem Quarterly $5^{2}$ (2013): 25-37. 
Tamari, Salim. The Great War and the Remaking of Palestine. Berkeley: University of California Press, 2017.

Tramontana, Felicita. "The Poll Tax and the Decline of the Christian Presence in the Palestinian Countryside in the 17th Century." Journal of the Economic and Social History of the Orient 56, nos. 4-5 (2013): 631-652.

Watenpaugh, Keith. Being Modern in the Middle East Revolution, Nationalism, Colonialism, and the Arab Middle Class. Princeton: Princeton University Press, 2006.

Zananiri, Sary. "From Still to Moving Image: the Shifting Representation of Jerusalem and Palestinians in the Western Biblical Imaginary", Jerusalem Quarterly 67 (2016): $64-81$. 